\title{
PENGARUH SUHU DAN LAMA PENYANGRAIAN TERHADAP TOTAL ASAM KOPI ARABIKA
}

\author{
Henny Poerwanty ${ }^{1)}$, Nildayanti' ${ }^{1)}$, Syahruni Thamrin ${ }^{1)}$, Andi Nur Fadliah ${ }^{1)}$, Alfian ${ }^{1)}$ \\ Jurusan Budidaya Tanaman Perkebunan, Politeknik Pertanian Negeri Pangkajene Kepulauan, \\ Pangkep, South Sulawesi, Indonesia \\ Email: hpoerwanty@gmail.com
}

\begin{abstract}
ABSTRAK
Penelitian ini bertujuan untuk mengetahui pengaruh suhu penyangraian terhadap total asam kopi yang dihasilkan dari beberapa metode pengolahan. Pengolahan buah kopi dilakukan dengan tiga pengolahan yaitu pengolahan basah (fermentasi dalam air selama 12 jam), pengolahan kering (tanpa fermentasi) dan fermentasi menggunakan teknologi Ohmic (OHM) dan dengan penambahan ekstrak nenas. Kopi hasil fermentasi dikeringkan hingga kadar air sekitar $11 \%$ bb kemudian disangrai pada tiga tingkat penyangraian light (193oC) dengan waktu 10 menit, medium $(203$ oC) dengan waktu 8 menit, dan dark (213oC) selama 7 menit. Hasil penelitian menunjukkan bahwa kopi yang diperoleh dari penyangraian pada tingkat medium kandungan kafein tertinggi pada pengolahan kering dengan total kafein 0,119\%, kemudian diikuti pengolahan basah dengan total kafein $0,087 \%$, dan kadar kafein terendah diperoleh dari kopi yang difermentasi menggunakan teknologi Ohmic dengan penambahan ekstrak nenas yaitu $0,047 \%$. Kandungan total asam tertinggi diperoleh dari kopi yang di fermentasi dengan menggunakan teknologi Ohmic dengan penambahan ekstrak nenas dengan kandungan total asam $0,0034 \%$, diikuti pada pengolahan basah $0,0033 \%$, dan total asam terendah diperoleh dari pengolahan kering dengan total asam $0,0032 \%$. Atribut aroma yang dihasilkan pada tingkat penyangraian medium memberikan aroma chocolate, caramel, fruity, dan earty. Sedangkan pada citarasa seduhan kopi meberikan rasa yang seimbang antara sweetness, acidity, bitteness, dan body yang tebal yang disukai oleh panelis.
\end{abstract}

Kata kunci: Fermentasi,Penyangraian, suhu dan waktu

\section{ABSTRACT}

This study aimed to determine the effect of roasting temperature on the scent of Arabica Coffee produced using several methods of processing. The processing of coffee fruit was conducted in three treatments, i.e the wet processing (the fermentation in wather for 12 hours), dry processing (without fermentation), and the fermentation using Ohmic (OHM) technology and with the addition of pineapple extract. The fermented coffee is dried until the water level reached the water level of $11 \% \mathrm{bb}$; then roasted on three levels of light $(193 \mathrm{oC})$ for 10 minutes, medium $(203 \mathrm{oC})$ for 8 minutes, and dark $(213 \mathrm{oC})$ for 7 minutes. The reseach results showed that the coffee obtained from the roasting at the medium level contained the highest caffeine content in the dry processing (the total kafein was $0,119 \%$ ) followed by the wet processing with the total caffeine of $0,087 \%$, and the lowest caffeine content was obtained from the fermentation processing using ohmic technology plus the pineapple extract with the total caffeine of $0,047 \%$. The highest acid content was obtained from coffee fermented using the ohmic technology plus the addition of pineapple extract with the content of $0,0034 \%$, followed by the wet processing with the content of $0,0033 \%$, and the lowest acid was obtained from the dry processing with the total content of $0,0032 \%$. The scent attributes generated from the medium processing gave the scents of chocolate, caramel, fruity, and earty. Meanwhile, the 
flavor of steeping coffee gove the balanced taste between sweetness, acidity, bitterness, and the thick body wich was favored by the panelists.

Key words: Fermentation, Roasting, Temperature and time

\section{PENDAHULUAN}

Kopi merupakan salah satu komoditi hasil perkebunan yang dijadikan suatu olahan minuman penyegar yang mempunyai citarasa yang sangat khas. Citarasa dan pengaruh fisikologis kesegarannya menyebabkan banyak diminati konsumen di seluruh dunia, sehingga memiliki nilai ekonomis yang cukup tinggi serta menjajikan untuk peningkatan ekonomi sebagai sumber devisa negara. Faktor yang mempengaruhi proses pembentukan citarasa khas dari kopi arabika dan robusta, diantaranya $75 \%$ teknik pengolahan pasca panen terutama dalam fermentasi yang akan mempengaruhi citarasa dan aroma kopi ketika diseduh. Sedangkan 25\% ditentukan oleh kondisi daerah produksi seperti keadaan tanah, ketinggian serta teknik budidaya yang dapat menghasilkan karakteristik yang berbeda (Puslitkoka Indonesia, 2011).

Indonesia negara Produsen kopi keempat terbesar dunia setelah Brazil, Vietnam dan Colombia. Perkembangan volume ekspor kopi Indonesia pada tahun 1980-2015 fluktuatif namun cenderung meningkat dengan pertumbuhan rata-rata sebesar 4,39\% per tahun (Kementrian Pertanian, 2016).

Penyangraian merupakan salah satu tahapan penting dari proses produksi kopi untuk konsumsi. Proses ini merupakan tahapan yang dapat membentuk aroma dan citarasa khas kopi yang akan dikeluarkan dari dalam biji kopi dengan perlakuan panas dan dipengaruhi oleh lamanya proses penyangraian. Menurut Reta et al., (2017), hasil penelitian perlakuan fermentasi terhadap biji kopi dengan menggunakan teknologi ohmic total asam dapat diturunkan, dari total asam dengan fermentasi tradisonal $0,73 \%$ menjadi $0,18 \%$ dengan perlakuan fermentaisi ohmic. Tetapi pada penelitian tersebut, tidak membedakan perlakuan pada tingkatan roasting.

Aroma dan citarasa kopi yang baik dapat dihasilkan dengan tahapan penyangraian menggunakan suhu yang tepat pada masing-masing tingkatan sangrai, sehingga produk kopi yang dihasilkan dapat mengeluarkan aroma yang dinginkan dan citarasa yang disukai oleh konsumen. Berdasarkan latar belakang diatas maka dilakukan penelitian tentang pengaruh perlakuan suhu penyangraian terhadap total asam biji kopi hasil fermentasi dengan menggunakan teknologi fermentasi ohmic dengan penambahan ekstrak nenas. 


\section{METODE}

Tahapan penelitian ini dilakukan dengan pengolahan buah kopi dengan pengolahan basah, pengolahan kering dan fermentasi menggunakan teknologi Ohmic kemudian dilanjutkan dengan penyangraian menggunakan mesin sangrai tipe W300 untuk menyangrai biji kopi (green coffee bean) dengan dua faktor pengamatan yaitu suhu dan waktu, dimana faktor suhu terbagi menjadi 3 tingkatan yaitu light dengan suhu $193^{\circ} \mathrm{C}$, medium dengan suhu $203^{\circ} \mathrm{C}$, dan dark dengan suhu $213^{\circ} \mathrm{C}$, sedangkan waktu penyangraian diatur secara manual dengan menggunakan stopwach. Rancangan percobaan yang diterapkan adalah rancangan acak lengkap, dan setiap perlakuan diulang sebanyak tiga kali.

Analisis total asam tertitrasi menggunkan metode AOAC (1995) dilakukan dengan mengambil 5 gr sampel diencerkan dengan menggunakan aquadest $50 \mathrm{ml}$, yang kemudian disaring dengan menggunakan kertas saring. Sampel yang telah disaring dimasukkan ke dalam labu takar $100 \mathrm{ml}$ dan diencerkan ke dalam aquades. Sampel yang diencerkan diambil sebanyak $5 \mathrm{ml}$ dan ditambahkan 2 tetes fenolflatein 1\%, setelah itu dilanjutkan dengan proses titrasi. Titrasi dilakukan dengan menggunakan larutan $\mathrm{NaOH} 0,1 \mathrm{~N}$ sampai timbul menjadi warna merah muda. Total asam titrasi diasumsikan sebagai total asam laktat.

$$
\text { Kadar asam laktat } \%=\frac{\mathrm{ml} \text { NaOH x N NaOH x BM x FP }}{\text { gr sampel x } 1000} \times 100
$$

Data hasil pengamatan diolah dengan analisis sidik ragam (analysis of variance) menggunakan software SPSS 16. Bila hasil dari analisi sidik ragam memperlihatkan pengaruh nyata $(\alpha<0,05)$, maka dilakukan uji beda nyata dengan menggunakan uji beda jarak berganda Duncen.

\section{HASIL DAN PEMBAHASAN}

Proses penyangraian biji kopi bergantung pada suhu dan lama proses pengolahannya. Proses penyangraian dapat diketahui dengan adanya perubahan kimiawi yang signifikan diantaranya terjadi kehilangan berat kering terutama gas $\mathrm{CO} 2$ yang sangat berkaitan dengan suhu penyangraian dan produk pirolisis lainnya. 


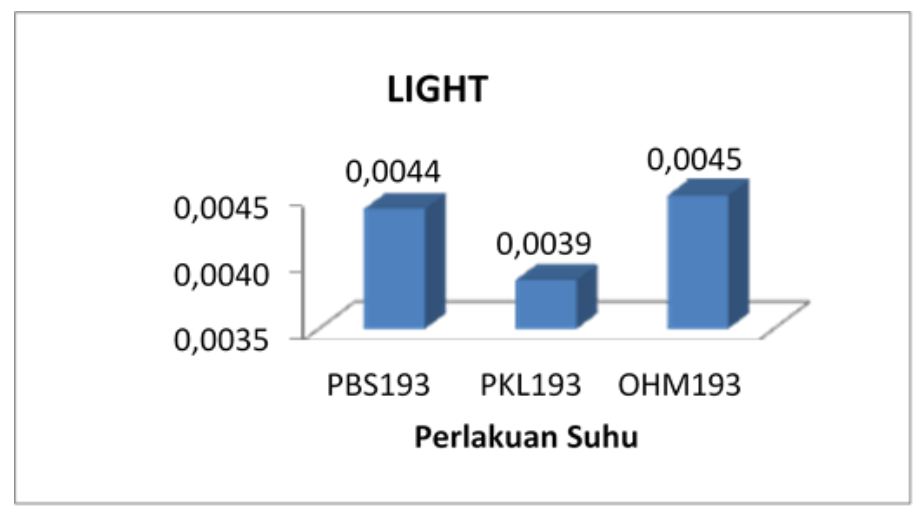

Gambar 1. Kandungan total asam kopi pada tingkatan Light

Gambar 1 memperlihatkan bahwa tingkatan penyangraian light mendapatkan nilai total asam terendah terdapat pada sampel PKL1930C sebesar 0,0039\%, kemudian pada PBS1930C sebesar 0,0044\%, dan total asam terting gi terdapat pada sampel OHM1930C sebesar 0,0045\%. Keasaman atau asiditas merupakan karakter biji kopi yang menetukan cita rasa tersendiri pada produk kopi dan menetukan tingkat kecerahan kopi. Biji kopi yang baik memiliki tingkat keasaman yang rendah. Keasaman yang terlalu tinggi membuat cita rasa kopi menjadi tidak nikmat. Tingkat keasaman biji kopi dipengaruhi oleh lokasi/ tempat tumbuh tanaman dan pengolahannya, suhu pemanggangan, jenis pemanggang, dan metode pemasakan (Anggara, 2011).

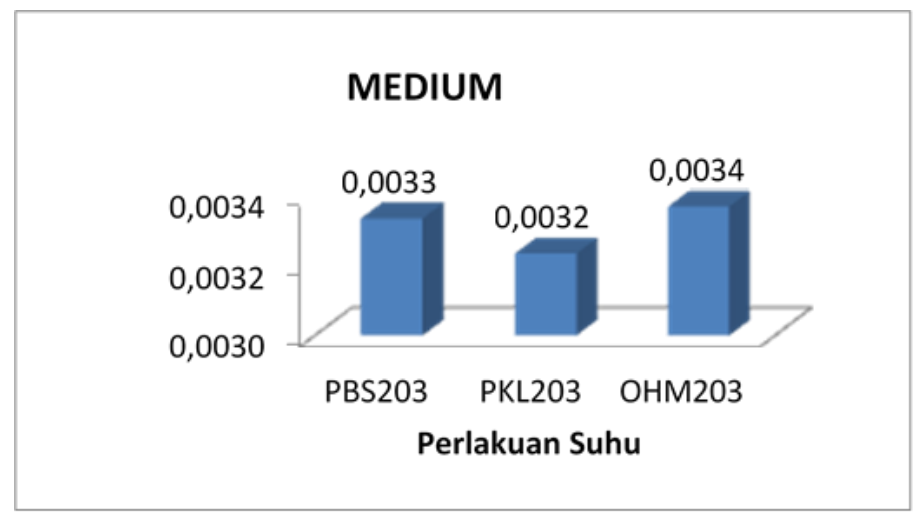

Gambar 2. Kandungan total asam kopi pada tingkatan Medium

Gambar 2 memperlihatkan bahwa bahwa tingkatan penyangraian medium mendapatkan total asam terendah terdapat pada sampel PKL203 sebesar 0,0032\%, kemudian PBS203 sebanyak 0,0033\%, kemudian total asam tertinggi terdapat pada sampel OHM203 sebanyak $0,0034 \%$. Pada tingkatan medium menujukkan total asam mengalami penurunan di bandingkan dengan tingkatan penyangraian light. Menurut Reta et al., (2017), bahwa perlakuan fermentasi terhadap biji kopi dengan menggunakan teknologi ohmic total asam dapat 
diturunkan dari total asam dengan fermentasi tradisonal $0,73 \%$ menjadi $0,18 \%$ dengan perlakuan fermentasi ohmic.

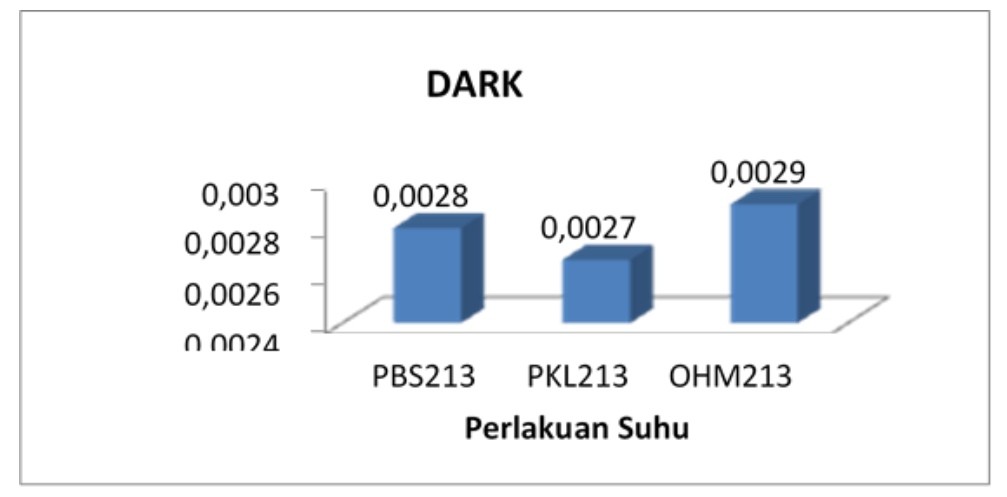

Gambar 3. Rata-rata kandungan total asam kopi pada tingkatan Dark

Gambar 3 memperlihatkan bahwa Pada tingkatan penyangraian dark total asam terendah terdapat pada sampel PKL213 sebanyak 0,0027\%, kemudian pada sampel PBS213 sebanyak 0,0028\% dan tertinggi pada sampel OHM213 sebanyak 0,0029\%, hasil total asam dari penyangraian dark semakin menurun dibandingkan dengan penyangraian medium. Penyangraian terbaik dari hasil penelitian ini diperoleh pada tingkat medium (203oC), yang mengeluarkan aroma dan flavor akibat terjadinya reaksi maillard.

Menurut Purnamayanti et al.,(2017), bahwa komponen aroma sudah muncul dari penyangraian medium kopi arabika dan hal ini sekaligus menunjukkan penyangraian yang optimum untuk kopi arabika. Rasa asam yang terdeteksi pada seduhan kopi berasal dari kandungan asam yang ada dalam kopi, yaitu dari kelompok asam karboksilat pada biji kopi antara lain asam format, asam asetat, asam oksalat, asam sitrat, asam laktat, asam malat, dan asam quinat.

\section{KESIMPULAN DAN SARAN}

Berdasarkan penelitian yang dilakukan mengenai pengaruh suhu penyangraian terhadap aroma kopi dari hasil pengolahan basah, pengolahan kering, dan fermentasi menggunakan teknologi Ohmic dengan penambahan ekstrak nenas dapat disimpulkan bahwa Suhu penyangraian dan metode pengolahan memberikan pengaruh terhadap total asam kopi seduhan. Hasil terbaik pada perlakuan suhu penyangraian 203oC dengan fermentasi menggunakn Ohmic dengan menghasilkan total asam tertinggi $(0,0034 \%)$ dibandingakan denga fermentasi basah $(0,0032 \%)$ dan pada pengolahan kering $(0,0032 \%)$. Perlu dilakukan lebih lanjut penelitian pada level suhu yang sama untuk ketiga tingkatan level penyangraian. 


\section{UCAPAN TERIMA KASIH}

Dismapaikan terima kasih dan penghargaan kepada Direktorat Jenderal Pendidikan Vokasi, Kementerian Pendidikan dan Kebudayaan (Kemendikbud) yang telah mendanai penelitian ini.

\section{DAFTAR PUSTAKA}

Anggara A. \& Marini S. (2011). Kopi Si Hitam Menguntungkan: Budidaya dan Pemasaran. Cahaya Atma Pustaka: Yogyakarta

Association of Official Analytical Chemists (AOAC). (1995). Official methods of analysis of the association of official analytical chemists. Arlington: AOAC.

Kementerian Pertanian. (2016). Outlook Kopi Komoditas Pertanian Subsektor Perkebunan. Departemen Pertanian. ISN : 1907-1507

Purnamayanti N.P.A., Gunadya I.B.P., \& Arda G. (2017). The effects of roasting temperature and Roasting duration on Physical characteristisc and sensory quality of arabica coffee (Kopi Arabica L) Volume-5 Nomor 2.

Puslitkoka Indonesia. (2011). Secangkir Kopi Meracik Tradisi. ISBN (78-979-8745-13-3. Edisi Pertama.

Reta., Mursalim., Salengke., Junaedi M., Mariati., \& Shopade P. (2017). Reducing the acidity of Arabica coffee beans by ohmic fermentation technology 